\title{
Immune response of teleost fish to helminth parasite infection
}

Resposta imune de peixes teleósteos às infecçôes por parasitos helmintos

Damy Caroline de Melo Souza ${ }^{1}$; Maria Cristina dos Santos²; Edsandra Campos Chagas ${ }^{1,3 *}$ (1)

\author{
${ }^{1}$ Programa de Pós-graduação em Ciências Pesqueiras nos Trópicos, Universidade Federal do Amazonas - UFAM, Manaus, AM, Brasil \\ ${ }^{2}$ Departamento de Parasitologia, Universidade Federal do Amazonas - UFAM, Manaus, AM, Brasil \\ ${ }^{3}$ Embrapa Amazônia Ocidental, Manaus, AM, Brasil
}

Received April 16, 2019

Accepted September 5, 2019

\begin{abstract}
Fish immune systems have become the subject of several studies due to the growing development of aquaculture and fisheries, and the demand for healthy produce for human consumption. Among the parasites responsible for diseases in fish farming, helminths stand out because they cause infections in farmed fish and decrease food conversion, zootechnical performance and meat quality. In the present review, the components that participate in the innate and adaptive immune responses of teleost fish that have so far been described are presented in order to summarize the defenses that these hosts have recourse to, in combating different groups of helminth parasites.
\end{abstract}

Keywords: Parasites, immune system, aquaculture.

\section{Resumo}

O sistema imune dos peixes tem se tornado alvo de muitas pesquisas devido ao crescente desenvolvimento da aquicultura e da pesca, assim como a exigência de obtençáo de animais saudáveis para o consumo humano. Dentre os parasitos responsáveis pelas enfermidades na piscicultura, os helmintos destacam-se por causarem infecçóes nos peixes cultivados e por ocasionarem diminuição da conversão alimentar, do desempenho zootécnico e da qualidade da carne. Nesta revisão, apresentaremos os componentes que participam das respostas imunes inata e adaptativa dos peixes teleósteos já descritos, a fim de sintetizar à quais defesas o hospedeiro recorre frente aos diferentes grupos de parasitos.

Palavras-chave: Parasitos, sistema imune, aquicultura.

\section{Introduction}

Studies on fish immune systems have increasingly gained attention due to the growing development of aquaculture, given that occurrence of infections in fish is harmful to the entire production chain (LEUNG \& BATES, 2013; TAVARES-DIAS \& MARTINS, 2017). Considering the conditions to which fish are subjected in farming systems, such as confinement, high density, excessive handling and transportation, their susceptibility to infectious agents due to the stress produced is greater (OBA et al., 2009; MAGNADÓTTIR, 2010). Besides that, the suppressive effect in immune system of fishes is observed not only after handling in farming systems but also as a consequence of deficiencies in environmental quality (oxygen, $\mathrm{pH}$, temperature and ammonia levels, among others) and in diet (DECOSTERE et al., 1999; SALVADOR et al., 2003; TORT, 2011).

The diversity of helminths that infect farmed fishes is lower when compared to wild fishes (HEUCH et al., 2011; LI et al., 2018) due

*Corresponding author: Edsandra Campos Chagas. Embrapa Amazônia Ocidental, Rodovia AM-010, Km 29, CP 319, CEP 69010-970, Manaus, AM, Brasil. e-mail: edsandra.chagas@embrapa.br to restriction in contact between host and parasites, however, the infection levels in farmed fishes is higher, condition that is usually attributed to higher fishes densities (VIOLANTE-GONZÁLEZ et al., 2009; COSTA et al., 2019). In turn, wild fish are more susceptible to co-infections due to the diversity of parasites that are found in environment. In this condition, the host immune system response can be modulated by one pathogen influencing its response to the subsequent infections, resulting in immune suppression or in a faster response to infection (SCHMIDT-POSTHAUS et al., 2013; KOTOB et al., 2017).

For example, Roon et al. (2015) demonstrated that an infection by trematode Nanophyetus salmincola impaired the immune response and increased the mortality of Oncorhynchus tshawytscha when exposed to Flavobacterium columnare. Thus, the primary infection has a direct impact in survival of fish in natural environment. Despite this, co-infection of parasites in fish are very common in nature, either the relationship between the parasites are synergetic or antagonistic, shaping the community dynamics (BARTOLI \& BOUDOURESQUE, 2007; HOSHINO et al., 2016). 


\section{Immune System of Teleost Fish}

The immune system acts in defense against infections caused by non-self agents in all living beings, in immune surveillance (to avoid appearance of tumors) and in maintenance of vital functions (homeostasis), even in hostile environments (OLABUENAGA, 2000). Didactically, the immune system is divided into the innate immune system (IIS) and the adaptive immune system (AIS). The components of the IIS trigger an immediate broad-spectrum response because they recognize vital compounds that can be found in the major groups of pathogens (URIBE et al., 2011). This response directs and activates the AIS, which in turn assembles a specific response for each antigen (immunogen). The IIS response usually has the same response time in each contact with antigens, while the AIS presents a faster response in subsequent contacts with induction agents because it produces memory cells. Therefore, cell and molecular components of IIS and AIS act together and simultaneously in relation to defense mechanisms and maintenance of homeostasis (SECOMBES \& WANG, 2012).

\section{Fish innate immune system}

The components of the innate immune system, such as pattern recognition receptors (PRR), are found in all vertebrates and in some invertebrates, and have also already been described in several plant species (JONES \& DANGL, 2006; GHOSH et al., 2011). Teleost fish have an IIS composed of physical barriers formed by scales, epidermis and mucus; chemical barriers such as serum epithelial lysozymes, molecules of the complement system, antibacterial peptides and lectins in the coating mucus; and microbiological barriers formed by commensal bacteria in the skin, gills, and intestines of these fish (WATTS et al., 2001; GÓMEZ \& BALCÁZAR, 2008).

A variety of humoral components, such as transferrin, interferon, inhibitory proteins, lysozymes acting alone or in cascades, antiproteases, type $\mathrm{C}$ lectins, pentraxins, natural antibodies, cytokines and chemokines can be found in the plasma, mucus and other body fluids (MAGNADÓTTIR, 2006). In addition to these components, fish present leukocytes analogous to those found in mammals, such as macrophages, eosinophils and others polymorphonuclear leukocytes (LIESCHKE \& TREDE, 2009). Macrophages and other leukocytes are particularly important in inflammatory processes and have the advantage of being able to rapidly mobilize a large number of cells because they have receptors that recognize a wide range of pathogens (SECOMBES, 1996; URIBE et al., 2011).

\section{Fish adaptive immune system}

The AIS only appeared, in terms of evolution, approximately 525 million years ago. It formed a defense system that became increasingly important and sophisticated as jawed vertebrate predators came into existence (FLAJNIK \& KASAHARA, 2010). The recombination activation genes (RAG1 and RAG2) are responsible for the rearrangement of immunoglobulin $\mathrm{D}$ (diversity) J (junction) gene (D) gene segments, producing a diversity of antigen receptors expressed on $\mathrm{T}$ and $\mathrm{B}$ lymphocyte membranes. The antigenic peptides presented by major histocompatibility complex (MHC) of class I and class II molecules interact directly with cytotoxic and auxiliary $\mathrm{T}$ lymphocytes receptors, respectively (COOPER \& ALDER, 2006). Thus, the adaptive immune response consists of a complex network that involves specialized cells, proteins, genes and cell signaling mechanisms, in order to allow organisms to specifically respond to antigens.

Immunoglobulins (antibodies) in teleost fish can be produced by B-lymphocytes, both from the IIS (B1) and from the AIS (B2). The predominant class of immunoglobulin in teleost fish is M (IgM) (ACTON et al., 1971). However, two other classes of immunoglobulins can also be identified: $\mathrm{IgT} / \mathrm{IgZ}$ (DANILOVA et al., 2005) and IgD (EDHOLM et al., 2010). Class IgT has been associated with the immunity of the intestinal mucosa (ZHANG et al., 2010). In rainbow trout (Oncorhynchus mykiss), Zhang et al. (2011) detected higher levels of IgT in the intestinal mucosa and higher levels of IgM in plasma, in response to intestinal infection caused by bacteria. This suggests that the immunoglobulin IgT presents specialized action in the intestinal mucosa. However, the function of this immunoglobulin and the processes that trigger its production remain unknown, but is likely to have similar functions to mammalian IgD (MASHOOF \& CRISCITIELLO, 2016). In teleost fish, antibodies can be found in their skin, intestines, gills, bile and, systemically, in plasma. The immune response of the skin, gills and intestines is particularly important, since these present direct contact with the environment (URIBE et al., 2011).

\section{Immune organs}

Production of immune system cells, i.e. myelopoiesis, occurs in the cephalic kidney and in the spleen, given that fish do not present bone marrow. The cephalic kidney is responsible for hematopoiesis and produces cells that enable phagocytosis and production and secretion of a large proportion of the immunoglobulins, and that also enable immunological memory (ZAPATA et al., 2006; WHYTE, 2007). The thymus is a primary lymphoid organ located close to the opercular cavity of fish that has the function of producing $\mathrm{T}$ lymphocytes (BOWDEN et al., 2005). Differently from mammals, the development of the thymus in fish depends more on hormonal factors and seasonal changes than on age (RAUTA et al., 2012).

The spleen is a secondary lymphoid organ in which antigens are captured from the bloodstream, antibodies are processed and B lymphocytes are activated and differentiated. It thus plays an important role in starting the adaptive immune response (WHYTE et al., 1990; BROMAGE et al., 2004; SALINAS et al., 2011).

The mucosa-associated lymphoid tissue (MALT) in teleost fish protects the intestines, skin and gills. Although MALT does not present any form of organization resembling Peyer's patches in mammals, it presents macrophages, lymphocytes, plasma cells, mast cells and other granulocytes that are seen in the lamina propria of epithelial tissues (PRESS \& EVENSEN, 1999). The antibodies found in MALT present spatial and quantitative differences in relation to the antibodies found in plasma, thus showing that MALT is locally able to promote antigen capture 
and antibody production (SALINAS et al., 2011; XU et al., 2013; ROMBOUT et al., 2014).

\section{Fish Diseases and Triggering of the Immune Response}

The immune response in teleost fish can be modulated by environmental and hormonal factors, nutritional state and the phase of life of the fish (BOWDEN, 2008; RAUTA et al., 2012; MARTIN \& KRÓL, 2017; SZWEJSER et al., 2017). In their natural environment, fish are parasitized by various groups, such as protozoa, myxosporeans, crustaceans and helminths (THATCHER, 2000; MALTA et al., 2001; FISCHER et al., 2003; LUQUE, 2004; WIEGERTJES et al., 2005; CAMPOS et al., 2008; ARAÚJO et al., 2009a). Although the diversity of parasite helminths in farmed fish is lower than in wild fish, parasitism is more easily disseminated in fish farms because the high densities of fish contribute towards spreading of pathogens (MAGNADÓTTIR, 2010).

Among the various pathogenic agents responsible for causing diseases in fish, helminths are a group of parasites that present epidemiological importance because the injuries that they cause favor occurrences of secondary infections, thus hampering the diagnosis and treatment (PYLKKÖ et al., 2006; MDEGELA et al., 2011; KOTOB et al., 2017). In addition, helminth infection can also lead to hematological and metabolic alterations that may be harmful to the health of fish, compromising fish survival, feed conversion, and consequently their grow rate (HIRAZAWA et al., 2016; ROCHA et al., 2018). Therefore, the present review provide an overview of the efforts that has been made to understand fish reactions to helminth infection, highlighting the main immune responses of teleost fish to infections caused by these parasites

\section{Infection by helminths in teleost fish}

"Helminth" is a generic term that is used to refer to worms that belong to the phyla Platyhelminthes, Nematoda and Acanthocephala. These worms cause infections both in vertebrates and in invertebrates and most of these parasites have co-evolved with their hosts (SITJÀ-BOBADILLA, 2008). Regarding the phylum Platyhelminthes, the species that belong to the classes Trematoda, Cestoda and Monogenea (EHLERS, 1986) are all parasites, and are responsible for occurrences of diseases in several economically important fish species (OGAWA, 2015). However, both parasitic and free-living species can be found in the phyla Nematoda and Acanthocephala.

Monogenea are mostly ectoparasites, and are mainly found in the gills, nostrils, eyes and body surface of fish. In turn, helminths such as trematodes, cestodes, acanthocephalans and nematodes are endoparasites that may infect the eyes, muscles and gastrointestinal tract (GROBBELAAR et al., 2015; OGAWA, 2015; DEZFULI et al., 2016). As reviewed by Sitjà-Bobadilla (2008), helminths have evolved using strategies of evading the immune system of fish, such that, among other strategies, they are able to mask their antigens by bonding to the host's molecules, incorporate these molecules in their surface layer and explore the host's immune response itself in order to increase their adhesion to the infection area. On the other hand, fish immune system respond with the aim of eliminating parasites or coexisting with them when attempts to eliminate them fail.

One of the main and most frequent reactions of fish intestines against parasites consists of hyperplasia of mucus-producing cells, which leads to excessive secretion of mucus around parasites (DEZFULI et al., 2016). The tissue damage caused by helminth infections induces rapid production of cytokines and chemokines by innate immunity cells, such as ILC2s (type 2 innate lymphoid cells), with mobilization of neutrophils, basophils and eosinophils (HARRIS \& LOKE, 2017).

The cell response to infection can vary, depending on the type of injury caused by parasites and their depth of penetration. Rodlet cells are granular leukocytes that are only found in teleost fish. They are mainly recruited in cases of infections caused by helminths or by the presence of harmful agents in tissues (REITE \& EVENSEN, 2006). These cells participate in the inflammatory response when helminths are only adhering to the intestinal epithelium, while the presence of granulocytes and macrophages increases as penetration into the intestinal wall becomes deeper (DEZFULI et al., 2011). In fish parasitized by helminths, large numbers of mast cells have been found in infected regions, thus indicating that this cell type has a relationship with the response to these parasites (REITE \& EVENSEN, 2006; DEZFULI et al., 2013).

When parasites infect the host's tissues, the damaged/dead cells release alarmins, also known as damage-associated molecular patterns (DAMPs), which promote inflammatory responses. Alarmins stimulate macrophages, dendritic cells and local mast cells to release pro-inflammatory cytokines and chemokines, which will result in leukocyte migration into the infected region (BIANCHI, 2007). Tumor necrosis factor alpha (TNF- $\alpha$ ) stimulates local release of cytokines and chemokines, thereby attracting neutrophils into tissue injury sites and promoting antigen presentation, phagocytosis and co-stimulation of T lymphocytes. Interleukin- $1 \beta$ is a type of cytokine that stimulates production of mucus, degranulation of eosinophils/basophils and increased adhesion of neutrophils to vascular endothelium (SECOMBES et al., 2001). Interleukin-6 seems to play an important role in regulation of the transition between the inflammatory phase, with predominance of neutrophils, and the phase in which macrophages predominate (COSTA et al., 2011) (Figure 1A).

Production of immunoglobulins can occur locally in the mucosa as a consequence of antigen capture by intraepithelial lymphocytes (antigen-presenting B lymphocytes), macrophages and dendritic cells (LUGO-VILLARINO et al., 2010; ROMBOUT et al., 2011). These cells present antigens to auxiliary $T$ lymphocytes that, in turn, co-stimulate B lymphocytes (via interleukin-4) so as to activate them and stimulate their differentiation (ZHU et al., 2012). In addition, auxiliary $T$ lymphocytes promote the final differentiation of B lymphocytes into plasma cells. Plasma cells secrete immunoglobulins (predominantly $\operatorname{IgM}$ and $\operatorname{IgT} / \operatorname{IgZ}$ in the mucosa) that may permeate body fluids or be transported into the mucus by polymeric immunoglobulin receptors (pIgR) (ROMBOUT et al., 2014) (Figure 1B).

It is believed that the spleen is the main lymphoid organ associated with the production of systemic antibodies in fish 


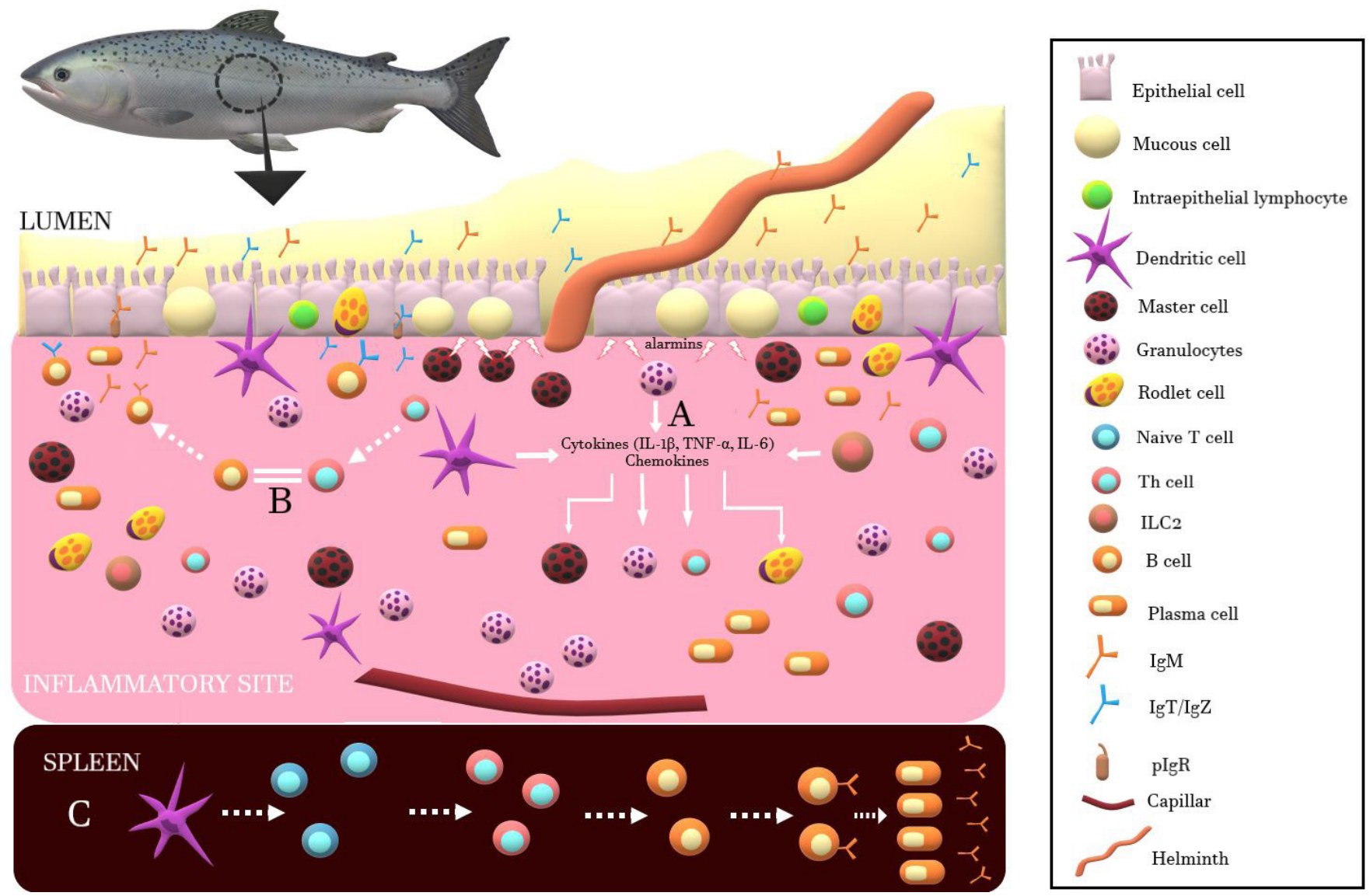

Figure 1. Fish immune response to parasite helminths. Illustration by Damy Caroline de Melo Souza.

(YE et al., 2013). In this organ, the antigens presented by dendritic cells activate naïve $\mathrm{T}$ lymphocytes and differentiate them into auxiliary $\mathrm{T}$ lymphocytes (via interleukin-4), which will activate and stimulate differentiation of B lymphocytes that are present in the marginal region of the spleen (lymphocytes B2). This results in production of systemic antibodies (Figure 1C). However, the increased production of antibodies that is detected as a response to various parasites may or may not result in acquired protection for the host (WOOD \& MATTHEWS, 1987; AIKEN et al., 2008; SANDOVAL-GÍO et al., 2008).

\section{Monogenea}

Monogeneans are mainly found parasitizing the gills and tegument of fish. Presence of these pathogens can cause chronic debility, reduced growth and, in some cases, fish mortality as a consequence of damage to the epithelial tissue, which act as a gateway for secondary infections caused by viruses, fungi and bacteria (THONEY \& HARGIS JR, 1991). In an analysis on the hematological and biochemical parameters of catfish (Pangasaianodon hypophthalmus) infected by Thaparocleidus sp., significant increases in leukocyte counts and plasma glucose levels were observed in groups with high and moderate levels of infection (KUMAR et al., 2018). Hirazawa et al. (2016) observed that groups of greater amberjack (Seriola dumerili) that were infected by the monogenean Neobenedenia girellae presented lower growth and reduced appetite and significant reductions in total proteins and globulins, compared with groups that were uninfected. Leukocytes alterations such as neutrophilia and lymphocytosis are usually observed in infection by monogeneans, and it is also related increases in hemoglobin concentration and the number of erythrocytes as a consequence of reduced respiratory surface in gills (TAVARES-DIAS et al., 2008; ARAÚJO et al., 2009b; MARINHO et al., 2015).

In a study on meagre (Argyrosomus regius) infected by Diplectanum sciaenae, Andree et al. (2015) reported occurrences of hyperplasia and severe injury to the lamellar epithelium, with moderate inflammation and presence of macrophages and lymphocytes in parasite anchorage regions. Faliex et al. (2008) studied the expression of genes associated with the immune response in European seabass (Dicentrarchus labrax) infected by Diplectanum aequans. They detected increased expression of interleukin-1 $\beta$ (IL-1 $\beta$ ) in the spleen and gills, which indicated the presence of a local inflammatory response. Dezfuli et al. (2010a) observed that hyperplasia and proliferation of mucous cells and rodlet cells occurred during the inflammatory response. In addition, a subpopulation of mast cells was found in the infected region, with presentation of piscidin-3 (an antimicrobial peptide) in cytoplasmic granules. This suggests that these cells participate in the response to these parasites. 
In addition to inflammatory responses, fish may also produce specific antibodies in occurrences of infections by monogeneans. For example, in rainbow trout $(O$. mykiss) the production of immunoglobulins specific to Discocotyle sagittata have been detected in fish sera. However, titration of these antibodies did not present any correlation with the intensity of infection (RUBIO-GODOY et al., 2003). On the other hand, Costa et al. (2019) observed that increases in total counts of leukocytes was significantly correlated with the intensity of infection caused by monogeneans in the gills of tambaqui (Colossoma macropomum). In addition, the parasitism as well as the level of immunoglobulins in tambaqui was higher in highest stocking densities, indicating that higher densities favors parasitism in these systems.

In turn, in olive flounders (Paralichthys olivaceus), a glycoprotein of the ciliated surface of the monogenean $N$. girellae was found to induce production of specific antibodies that were detected in the mucus and plasma of infected individuals. These antibodies presented agglutinating and immobilizing action against larvae of monogeneans, thus indicating that there was an integrated response between the IIS and AIS. Despite this, the study did not show any occurrence of acquired protection in cases of reinfection (HATANAKA et al., 2005). Further studies relating to the immune response to infections caused by monogeneans are listed in Table 1.

\section{Cestoda}

In fish infected by cestodes, the IIS induces an inflammatory reaction to adhesion structures of parasites in the intestinal mucosa (BUCHMANN \& LINDENSTRØM, 2002). Morley \& Hoole (1995) evaluated the structural modifications to the parasite-host interface of $C$. carpio that were infected by Khawia sinensis. They observed that the damage in regions where parasites adhered was

Table 1. Immune components of fish associated with responses to parasites.

\begin{tabular}{|c|c|c|c|c|}
\hline \multicolumn{5}{|c|}{ (a) } \\
\hline Parasite & Species & Host & $\begin{array}{l}\text { Immune response } \\
\end{array}$ & Reference \\
\hline \multirow[t]{12}{*}{ Monogenea } & Pseudodactylogyrus sp. & Anguilla anguilla & Acquired resistance (Unknown mechanism); & Slotved \& Buchmann (1993) \\
\hline & Neobenedenia girellae & Paralichtys olivaceus & Acquired resistance (Unknown mechanism); & $\begin{array}{l}\text { Bondad-Reantaso et al. } \\
(1995)\end{array}$ \\
\hline & Neobenedenia girellae & Paralichtys olivaceus & Increased IgM level & Wang et al.(1997) \\
\hline & Gyrodactylus derjavini & Oncorhynchus mykiss & Alternative complement pathway activation; & Buchmann (1998) \\
\hline & Gyrodactylus salaris & Salmo salar & $\begin{array}{l}\text { Alternative complement pathway activation: } \\
\text { factors in host serum and mucus; }\end{array}$ & Harris et al. (1998) \\
\hline & $\begin{array}{l}\text { Pseudodactylogyrus } \\
\text { anguillae }\end{array}$ & Anguilla anguilla & Antibody production; & Mazzanti et al. (1999) \\
\hline & $\begin{array}{l}\text { Neobeterobothrium } \\
\text { hirame }\end{array}$ & Paralichthys olivaceus & $\begin{array}{l}\text { Increased expression of genes related to } \\
\text { proteases, immunoglobulin light chain, } \\
\text { immunoglobulin heavy chain and B cell } \\
\text { differentiation; }\end{array}$ & Matsuyama et al. (2007) \\
\hline & Neobenedenia melleni & Oreochromis mossambicus & $\begin{array}{l}\text { Specific antibody production detected in host } \\
\text { serum and mucus; }\end{array}$ & Kishimori et al. (2015) \\
\hline & Neobenedenia melleni & Seriola lalandi & $\begin{array}{l}\text { Increased level of total protein concentration } \\
\text { in serum and anti-protease and } \\
\text { myeloperoxidase activity; }\end{array}$ & $\begin{array}{l}\text { Reyes-Becerril et al. } \\
(2017)\end{array}$ \\
\hline & Gyrodactylus kobayashii & Carassius auratus & $\begin{array}{l}\text { Increased expression of inflammatory genes: } \\
\text { IL-1 } \beta 2, T N F-\alpha 1 \text { and TNF- } \alpha 2 \text {; }\end{array}$ & Zhou et al. (2018) \\
\hline & Thaparocleidus sp. & $\begin{array}{l}\text { Pangasianodon } \\
\text { hypophthalmus }\end{array}$ & $\begin{array}{l}\text { Increased production of lactate } \\
\text { dehydrogenase, lactate, creatinine, serum } \\
\text { glutamate-oxaloacetate transaminase and } \\
\text { serum glutamate-pyruvate transaminase; }\end{array}$ & Kumar et al. (2018) \\
\hline & & & (b) & \\
\hline Parasite & Species & Host & Immune response & Reference \\
\hline \multirow[t]{2}{*}{ Cestoda } & Diphyllobothrium spp. & Salmo gairdneri & $\begin{array}{l}\text { Antibody production correlated with worm } \\
\text { burdens in individual fish; }\end{array}$ & Sharp et al.(1989) \\
\hline & $\begin{array}{l}\text { Diphyllobothrium } \\
\text { dendriticum }\end{array}$ & Oncorhynchus mykiss & $\begin{array}{l}\text { Antibody production after } 5 \text { weeks of } \\
\text { experimental infection; }\end{array}$ & Sharp et al. (1992) \\
\hline Ligula intestinalis & Rutilus rutilus & $\begin{array}{l}\text { Specific antibody } \\
\text { production to tegumental } \\
\text { antigens; }\end{array}$ & Williams \& Hoole (1992) & \\
\hline $\begin{array}{l}\text { Diphyllobothrium } \\
\text { dendriticum }\end{array}$ & Coregonus migratorius & $\begin{array}{l}\text { Suppression of antibody } \\
\text { production; }\end{array}$ & Mazur \& Tolochko (2015) & \\
\hline
\end{tabular}

(a) Monogenea; (b) Cestoda; (c) Trematoda; (d) Nematoda and (e) Acanthocephala. 
Table 1. Continued

\begin{tabular}{|c|c|c|c|c|}
\hline & & & (c) & \\
\hline Parasite & Species & Host & Immune response & Reference \\
\hline \multirow[t]{8}{*}{ Trematoda } & Telogaster opisthorchis & $\begin{array}{l}\text { Anguilla australis } \\
\text { schmidtii; } \\
\text { Anguilla dieffenbachii }\end{array}$ & $\begin{array}{l}\text { Antibody production detected in plasm and } \\
\text { intestinal mucus. }\end{array}$ & McArthur (1978) \\
\hline & $\begin{array}{l}\text { Diplostomum } \\
\text { spathaceum }\end{array}$ & Salmo gairdneri & $\begin{array}{l}\text { Acquired resistance } \\
\text { (Unknown mechanism). }\end{array}$ & $\begin{array}{l}\text { Stables \& Chappell } \\
(1986)\end{array}$ \\
\hline & $\begin{array}{l}\text { Diplostomum } \\
\text { spathaceum }\end{array}$ & Oncorhynchus mykiss & $\begin{array}{l}\text { Acquired resistance (increased level of total } \\
\text { immunoglobulins and in the proportion of } \\
\text { neutrophils and monocytes); }\end{array}$ & $\begin{array}{l}\text { Höglund \& Thuvander } \\
\text { (1990) }\end{array}$ \\
\hline & Rhipidocotyle fennica & Rutilus rutilus & $\begin{array}{l}\text { Acquired resistance (increased IgM } \\
\text { production); }\end{array}$ & Aaltonen et al. (1997) \\
\hline & $\begin{array}{l}\text { Diplostomum } \\
\text { spathaceum }\end{array}$ & Oncorhynchus mykiss & $\begin{array}{l}\text { Acquired resistance } \\
\text { (Unknown mechanism). }\end{array}$ & Karvonen et al. (2004) \\
\hline & Cardicola forsteri & Thunnus maccoyii & Acquired resistance (antibody production); & Aiken et al. (2008) \\
\hline & $\begin{array}{l}\text { Cardicola oriental; } \\
\text { Cardicola opisthorchis }\end{array}$ & Thunnus orientalis & $\begin{array}{l}\text { Increased transcription of IgM, MHC2, } \\
\text { TCR- } \beta \text { and IL- } 8 \text { in heart; Only IgM } \\
\text { increased transcription in gills; }\end{array}$ & Polinski et al. (2014) \\
\hline & & & (d) & \\
\hline Parasite & Species & Host & Immune response & Reference \\
\hline \multirow[t]{7}{*}{ Nematoda } & Anguillicola crassus & Anguilla anguilla & Specific antibody production & Buchmann et al. (1991) \\
\hline & Anisakis simplex & Pollachius virens & Acquired resistance (antibody production); & Priebe et al. (1991) \\
\hline & Anguillicola crassus & Anguilla anguilla & $\begin{array}{l}\text { Specific antibody production in response to } \\
\text { natural infection and injected whole-worm } \\
\text { extract; }\end{array}$ & $\begin{array}{l}\text { Höglund \& Pilström } \\
\text { (1994) }\end{array}$ \\
\hline & Anguillicola crassus & Anguilla anguilla & $\begin{array}{l}\text { Specific antibody production in response to } \\
\text { cuticle and gonad antigens; }\end{array}$ & $\begin{array}{l}\text { Nielsen \& Buchmann } \\
\text { (1997) }\end{array}$ \\
\hline & Anguillicola crassus & $\begin{array}{l}\text { Anguilla japonica; } \\
\text { Anguilla anguilla }\end{array}$ & $\begin{array}{l}\text { Specific antibody production; Acquired } \\
\text { resistance post-immunization in Anguilla } \\
\text { japonica; }\end{array}$ & Knopf \& Lucius (2008) \\
\hline & Anisakis simplex & Oncorhynchus mykiss & $\begin{array}{l}\text { Suppression of IgM transcription, increased } \\
\text { expression of CD4 and complement factor } \\
\text { C3; }\end{array}$ & Haarder et al. (2013) \\
\hline & & & (e) & \\
\hline Parasite & Species & Host & Immune response & Reference \\
\hline \multirow[t]{3}{*}{ Acanthocephala } & Dentitruncus truttae & Salmo trutta & $\begin{array}{l}\text { Increased number of master cells and } \\
\text { fibroblasts expressing proliferation cell nuclear } \\
\text { antigen (PCNA); }\end{array}$ & Dezfuli et al. (2012) \\
\hline & $\begin{array}{l}\text { Pomphorhynchus } \\
\text { kashmirensis }\end{array}$ & Schizothorax sp. & $\begin{array}{l}\text { Antibody production in response to somatic } \\
\text { antigens; }\end{array}$ & Nazir et al. (2013) \\
\hline & Acanthocephalus lucii & Esox lucius & $\begin{array}{l}\text { Master cells immunoreactive to piscidin- } 3 \text {, } \\
\text { lysozyme, interleukin- } 6 \text {, TNF - } \alpha \text {, } \\
\text { met-enkephalin; }\end{array}$ & Dezfuli et al. (2018) \\
\hline
\end{tabular}

(a) Monogenea; (b) Cestoda; (c) Trematoda; (d) Nematoda and (e) Acanthocephala.

minimal. This damage consisted of flattening of adjacent epithelial cells and increased mucus production around the parasites. There was also mobilization of cells such as macrophages, eosinophils and lymphocytes, which were even found as aggregates on the tegument of the parasites. In turn, in infection caused by Eubothrium crassum in O. mykiss, there was mild enteritis, epithelial flaking and vacuolization of epithelial cells, along with infiltration of mast cells and rodlet cells and granulation of the lamina propria and submucosa (BOSI et al., 2005). Abdelmonem et al. (2010) described an inflammation in the intestinal mucosa caused by Proteocephalus macrocephalus in eels (Anguilla anguilla), which indicated that hyperplasia of goblet cells was occurring and that, consequently, a large amount of mucus was covering parasites. Infiltration of leukocytes into the lamina propria was also observed.

Molnár et al. (2003) investigated infection of Atractolytocestus buronensis in C. carpio and found the epithelium had degenerated and been transformed into balloon-shaped epithelium. In some cases, there was also absence of contact between the epithelium and the parasites' bodies. In this same study, lymphocytes and monocytes were observed adhering to the parasites' bodies, at the adhesion sites. In infected Prussian carps (Carassius gibelio), metacestodes of Neogryporhynchus cheilancristrotus were found 
in the lamina propria of bowel folds, surrounded by lysed and fragmented connective tissue cells, with major infiltration by macrophages (MOLNÁR, 2005). In Silurus glanis, close to the adhesion sites for the parasite Glanitaenia osculata, it was reported that neutrophils and several mast cells were close to and/or in contact with endocrine cells and mucous cells, thus indicating that an interaction between these cells was present during the regulation process of the inflammatory response (DEZFULI et al., 2017).

Nie \& Hoole (1999) evaluated the antibody response in C. carpio that were naturally infected by Bothriocephalus acheilognathi, and after intraperitoneal administration of an extract made from parasite bodies. Production of specific antibodies was observed three weeks after injection of the extract, and increased numbers of antibodies and plasma cells in the plasma were observed in the naturally infected fish. However, these numbers were not significantly higher than in the uninfected group. In relation to this group of parasites, it has also observed in some studies that parasites modulate the host's immune response (as an evasion strategy), thereby inhibiting production of antibodies and the activity of T lymphocytes (MAZUR \& TOLOCHKO, 2015). Other studies relating to the immune response to infections by cestodes are listed in Table 1 .

\section{Trematoda}

Infections caused by adult trematodes only rarely cause severe diseases or lead fish to death. However, in most cases, they induce local inflammatory responses. On the other hand, entry and migration of metacercariae in tissues may cause local hemorrhage and tissue damage (WOO et al., 2011). In addition, infection by trematodes may increase the susceptibility of fish to infection by bacteria, thus inducing a more exacerbated inflammatory response (PYLKKÖ et al., 2006). Infections caused by trematodes in $A$. anguilla mainly damage the villi of the mucosal epithelium. According to Dezfuli et al. (2015), the parasites found in intestines were covered by a thick layer of adherent mucus. In this region, a large number of rodlet cells and mucosal cells was found. In turn, in Tinca tinca, infection by trematodes in the gills, intestine, spleen, kidney and heart produced granulomas around metacercariae that were encysted in the submucosa, muscle and serous layer. Mobilization of mast cells, rodlet cells and neutrophils was also seen; and formation of melanomacrophage centers, i.e. macrophages containing melanin pigments, was present (DEZFULI et al., 2013).

In a study on Pacific bluefin tunas (Thunnus orientalis) that presented infection by Didymocystis wedli in their gills, increased levels of interleukin- $1 \beta$ and TNF- $\alpha$ were observed. In this organ, parasites were also found encysted in the fibrous layer of the connective tissue, but with only a small number of lymphocytes (MLADINEO \& BLOCK, 2010). Constenla et al. (2011) observed that in situations of infection by Bathycreadium elongatum in Trachyrincus scabrus, several nodules were formed in the pyloric cecum, in which degraded digeneans were found. These nodules presented granulomas with several layers of connective tissue, and macrophages were the most abundant cells.

Cell responses to infections by Sanguinicola inermis in C. carpio was also found to induce production of specific antibodies and activation of complement system proteins in plasma (ROBERTS et al., 2005). These responses were positively correlated with higher room temperature, thus showing that this factor also influences the immune response in these fish. In another study conducted on $O$. mykiss, macrophages presented a larvicidal activity against the infecting phases of Diplostomum spathaceum. It was also observed that the action of macrophages was greater when specific antibodies were present, with reduction in the number of species of Diplostomidae in the eyes of immunized trout (WHYTE et al., 1990). Other studies that have report the immune responses to infections by trematodes are listed in Table 1.

Trematodiasis in humans due to infection of fish-borne trematodes are largely described in literature (CHAI et al., 2005; SRIPA et al., 2010). Particularly, the liver flukes (family: Opisthorchiidae) are of public health importance, since they cause several diseases as pancreatitis, cholangiocarcinoma and cholangitis, and are acquired from a wide range of intermediate host, which hampers these parasite control (HUNG et al., 2013). The main cause of human infection is the consumption of raw or undercooked fish, which has become a widespread fashion in the world, making it easier to parasite dissemination.

\section{Nematoda}

In a study conducted by Dezfuli et al. (2016), the damage caused by the nematode Contracaecum rudolphii in the intestines of A. anguilla was found to result in formation of granulomas, with a high number of mast cells in the outer regions, and fibroblasts in the innermost regions. In specimens of pirarucu (Arapaima gigas), infection by Spirocamallanus inopinatus resulted in focal necrosis areas, flaking of epithelium, hemorrhage, inflammatory infiltrate and formation of fibrous capsules around parasites (GAINES et al., 2012). Besides that, in infection by nematodes is usually observed alterations in hematological parameters such as increase in total leukocytes count and mean corpuscular volume of erythrocytes (KUNDU et al., 2016; MARTINS et al., 2017).

In South American silver croakers (Plagioscion squamosissimus) infected by nematodes of the family Anisakidae, the parasites were found in cysts composed of multilayered connective tissue and a membranous capsule with collagenous fibers, which were surrounded by aggregates of macrophages and amorphous substance (MELO et al., 2014). Larvae of the nematode Anisakis simplex infecting European flounders (Platichthys flesus) were found encapsulated in the serous layer in the outer surface of the intestine, with presence of rodlet cells and aggregates of macrophages in cysts in infected livers and spleens (DEZFULI et al., 2007). Therefore, this seems to be the strategy used by the immune system to avoid parasite migration and development in hosts' tissues, thus preventing possible tissue damage caused by this migration.

On the other hand, this may also be a strategy for evading immune system reactions, since some products excreted or secreted by nematodes may decrease the activation of several important genes relating to the immune system (BAHLOOL et al., 2013). Other studies have already detected specific antibodies for nematode parasites in some species, although this characteristic does not present any direct relationship with the ability of hosts 
to eliminate parasites. However, it may indicate higher resistance to future infections (COSCIA \& ORESTE, 1998, 2000). Other studies relating to the immune response to infections by nematodes are listed in Table 1.

Nematodes are parasites of particular interest on studies evaluating potential zoonotic diseases, since its larvae has a tendency of encysting in fish muscle, which is usually the paratenic or intermediate host in the life cycle of nematodes (BUCHMANN \& MEHRDANA, 2016). The most fish-borne nematodes found in humans are members of Anisakidae and Gnathostomatidae families, and Capillaria philippinensis of Trichinellidae family (EIRAS et al., 2018). The nematodes of these families are reported as parasites of many species of marine and freshwater fishes, but infection in humans can occur by consuming fishes alive, raw or undercooked (CAVALCANTI et al., 2012; ANDRADE-PORTO et al., 2015; RODRIGUES et al., 2015).

\section{Acanthocephala}

In infections caused by acanthocephalans such as Pomphorhynchus laevis, penetration through all layers of the mucosa, from the epithelial to the serous mucosa, may occur. In this type of infection, the immune system of the host reacts by increasing the mobilization of cells such as neutrophils, plasma cells, lymphocytes and fibroblasts, thus forming a composite fibrous layer, along with local mast cells, in the inflamed tissue (WANSTALL et al., 1986). This encapsulating process was described by Dezfuli et al. (2015) in which hosts presented a series of spirals of fibrous elements. There were a few degenerated epithelial cells and, close to the parasites, a large number of mast cells among the fibers, along with some granules of mast cells that had migrated into the pores of the parasite's tegument.

Martins et al. (2001) described infection in specimens of "curimbatá" (Prochilodus lineatus) caused by the acanthocephalan Neoechinorhynchus curemai. This gave rise to complete flaking of the intestinal mucosal epithelium. In addition, severe hyperplasia and hypertrophy of goblet cells and a severe inflammatory reaction, with major infiltration of eosinophils and mononuclear leukocytes, were observed. Belo et al. (2013) also described hematological alterations caused by $N$. curemai in specimens of "curimbatá" (P. lineatus). They reported that there were greater numbers of monocytes and smaller numbers of thrombocytes, compared with non-parasitized fish.

In the hybrid species "patinga" (Piaractus mesopotamicus $\mathrm{x}$ Piaractus brachypomus), the intestinal mucosa presented flaking and there were infiltrations of mast cells and increased lymphocyte and neutrophil counts in the region where the parasite Echinorhynchus jucundus adhered (VENTURA et al., 2017). In specimens of ripsaw catfish (Oxydoras niger), occurrences of metazoan parasites such as the acanthocephalan Paracavisona impudica caused increased neutrophil counts and decreased lymphocyte counts in the blood (SANTOS \& TAVARES-DIAS, 2010). In addition, in carps (Cyprinus sp.) and snow trout (Schizothorax sp.), eosinophilia was described and were ascribed to damage possibly caused by acanthocephalans (SHAH et al., 2009).
In regions infected by Echinorhynchus truttae and Cyathocephalus truncatus in $S$. trutta, the bowel villi were damaged such that there were losses, necrosis and degeneration of intestinal epithelia. At points where proboscides adhered, high numbers of lymphocytes, mast cells, eosinophils and collagenous fibers were observed, and the number of mucous cells was much larger than in regions where adhesion did not occur (MLADINEO et al., 2009; DEZFULI et al., 2010b). In specimens of S. trutta parasitized by Dentitruncus truttae, most parasites did not go beyond the granular layer, but some specimens were observed to have their proboscides in muscle layers (DEZFULI et al., 2008).

Jerônimo et al. (2017) observed that specimens of tambaqui (Colossoma macropomum) that were infected by the acanthocephalan Neoechinorhynchus buttnerae presented thickening and hardening of the intestinal wall. Histologically, an intense inflammatory reaction characterized by the presence of macrophages, dendritic cells and some lymphocytes was described, with formation of granulomas in the submucosal layer of some fish. Histochemical techniques revealed the presence of increased production of acidic mucous substances by hosts as a response to infection (MATOS et al., 2017). Hematological alterations were also observed in C. macropomum infected by $N$. buttnerae and others metazoan species, with a negative correlation between the abundance of acanthocephalans and parameters such as hematocrit, hemoglobin concentration and total thrombocytes (ROCHA et al., 2018).

In an evaluation on the immune response of European chubs (Squalius cephalus) that were either naturally or experimentally infected by P. laevis (Acanthocephala), Harris (1972) detected production of immunoglobulins both in the plasma and in the intestinal mucosa of infected fish. In quillbacks (Carpiodes cyprinus), titration of plasma antibodies was conducted by means of immunoprecipitation. The precipitation reaction was more intense against antigens of mature male and pregnant females of Neoechinorhynchus carpiodi. However, the greater the intensity of infection was, the lower the titers of antibodies were. Moreover, use of Evans blue staining (EB) showed that there was higher intensity of staining denoting presence of serum proteins in regions where nodules formed (SZALAI et al., 1988). Regarding the group Acanthocephala, few studies have yet addressed the humoral response of the immune system in teleost fish (Table 1). This is probably because few species have been correlated with teleost fish of high economic value or have been shown to cause severe damages to these fish.

\section{Alternatives for Diagnosis of Helminth Infection in Fish}

The efforts in diagnostic of helminth infections are mainly directed to those species that may cause diseases in human, once they have a direct impact in public health. Infections by helminths usually are diagnosticated by necropsy of animals and directly visualization of tissues under light microscope, which requires extensive laboratory work. New methods of detection and identification of helminths have been developed as a faster and less invasive alternative for diagnosis of pathogens in fishes (EL DEEN et al., 2018). 
Infections by nematodes are currently diagnosed by visual inspection of larvae parasite and histopathology analysis of fish muscle (GAMBOA et al., 2012). As an alternative, molecular techniques as real-time polymerase chain reaction (PCR) with high-resolution molecular analysis was employed to detect and quantify the presence of Anisakis simplex in fish, enabling even taxa differentiation of other parasites (JAISWAL et al., 2017). For fish products, usually it is used UV illumination, artificial digestion by the utilization of chloridric acid and pepsin, and recently it was developed a new method called TrichinEasy ${ }^{\circledR}$ digestion system, a confirmatory test of the presence of the larvae (CAMMILLERI et al., 2016).

Accidental ingestion of trematodes larvae in fish muscle is the main cause of its infection in human. Therefore, detection of liver fluke in fish is important for its prevention, especially in endemic areas. The usual method for diagnosis of liver fluke in fish is the enzymatic digestion of fish tissue and direct microscopy techniques (SRIPA et al., 2007) Cai et al. (2010) developed a loop-mediated isothermal amplification (LAMP) assay that allows a sensitive and fast detection of liver fluke Clonorchis sinensis metacercariae in fish. The method was 100 times more sensible than conventional PCR and could be applied as well to identification of other species of trematodes in fish.

For aquaculture, there is still a huge gap in diagnosis methods that could be applied to detection and accurately indicate a helminth infection in fish farm. Thereby, traditional method for diagnosis such as necropsy, examination of possible infected tissues and further analysis with light microscope (wet mount or stained parasites) are the routine in laboratories (EL DEEN et al., 2018).

\section{Final Remarks}

Regarding the immune response of teleost fish to infection by helminths, we observes that researchers have mainly evaluated the action of the IIS towards elimination of parasites belonging to the different groups. Rodlet cells and mast cells, accompanied by neutrophils and macrophages, are the main types of cells that have been described in infections caused by all groups of helminths. Hyperplasia and increased numbers of mucous cells in response to infection have also been observed, such that parasites become coated with the mucus thus produced. The importance of mucus in the immune response to infection is due to the physical protection (retardation of infection) that this provides, and because mucus contains immune chemical components that are able to damage the parasites tegument. A histopathological approach regarding infections in fish caused by helminths is highly relevant because this makes it possible to ascertain the damage that helminths really cause to fish and the degree of importance that should be attributed to such infections. More recent studies have sought to detect the participation of the AIS in production of immunoglobulins that are specific for parasites and, possibly, in production of various classes of immunoglobulins for different anatomical infection sites, such as the gills, tegument or intestine. Therefore, further studies are still necessary, in relation to various species of teleost fish, in order to verify the role of the AIS in elimination of parasites and acquisition of resistance against future infections (immunological memory). Still, there are many gaps in knowledge regarding the local and systemic immune responses that are developed by teleost fish. This hampers development of less invasive diagnoses, adequate treatments and effective prevention, especially regarding farmed fish. In addition, it is still necessary effort in development of cheaper and faster techniques for diagnoses of helminth parasites in fish, especially to those groups that are responsible for the transmission of diseases to humans. The studies for detection of helminths are more directed to its presence in human than in host fish. More approaches to helminth infection diagnosis in fish could help in prevention and in accurate treatment in cases of farmed fishes.

\section{References}

Aaltonen TM, Valtonen ET, Jokinen EI. Humoral response of roach (Rutilus rutilus) to digenean Rhipidocotyle fennica infection. Parasitology 1997; 114(3): 285-291. http://dx.doi.org/10.1017/S0031182096008499.

Abdelmonem AA, Metwally MM, Hussein HS, Elsheikha HM. Gross and microscopic pathological changes associated with parasitic infection in European eel (Anguilla anguilla, Linnaeus 1758). Parasitol Res 2010; 106(2): 463-469. http://dx.doi.org/10.1007/s00436-009-1688-2. PMid:19953271.

Acton RT, Weinheimer PF, Dupree HK, Russell TR, Wolcott M, Evans $\mathrm{EE}$, et al. Isolation and characterization of the immune macroglobulin from the paddlefish, Polyodon spathula. J Biol Chem 1971; 246(22): 6760-6769. PMid:5001610.

Aiken HM, Hayward CJ, Crosbie P, Watts M, Nowak BF. Serological evidence of an antibody response in farmed southern bluefin tuna naturally infected with the blood fluke Cardicola forsteri. Fish Shellfish Immunol 2008; 25(1-2): 66-75. http://dx.doi.org/10.1016/j.fsi.2007.12.010. PMid: 18502150 .

Andrade-Porto SM, Cárdenas MQ, Martins ML, Oliveira JKQ, Pereira JN, Araújo CSO, et al. First record of larvae of Hysterothylacium (Nematoda: Anisakidae) with zoonotic potential in the pirarucu Arapaima gigas (Osteichthyes: Arapaimidae) from South America. BrazJ Biol 2015; 75(4): 790-795. http://dx.doi.org/10.1590/1519-6984.22213. PMid:26675898.

Andree KB, Roque A, Duncan N, Gisbert E, Estevez A, Tsertou MI, et al. Diplectanum sciaenae (Van Beneden \& Hesse, 1863) (Monogenea) infecting meagre, Argyrosomus regius (Asso, 1801) broodstock in Catalonia, Spain. A case report. Vet Parasitol Reg Stud Rep 2015; 1-2: 75-79. http://dx.doi. org/10.1016/j.vprsr.2016.02.006. PMid:31018414.

Araújo CSO, Barros MC, Gomes ALS, Varella AMB, Viana GM, Silva NP, et al. Parasitas de populaçóes naturais e artificiais de tucunaré (Cichla spp.). Rev Bras Parasitol Vet 2009a; 18(1): 34-38. http://dx.doi. org/10.4322/rbpv.01801006. PMid:19500458.

Araújo CSO, Tavares-Dias M, Gomes ALS, Andrade SMS, Lemos JRG, Oliveira AT, et al. Infecçôes parasitárias e parâmetros sanguíneos em Arapaima gigas Schinz, 1822 (Arapaimidae) cultivados no estado do Amazonas, Brasil. In: Tavares-Dias M (Org.). Manejo e sanidade de peixes em cultivo. Macapá: Embrapa Amapá; 2009b. p. 389-424.

Bahlool QZ, Skovgaard A, Kania PW, Buchmann K. Effects of excretory/ secretory products from Anisakis simplex (Nematoda) on immune gene expression in rainbow trout (Oncorhynchus mykiss). Fish Shellfish Immunol 2013; 35(3): 734-739. http://dx.doi.org/10.1016/j.fsi.2013.06.007. PMid:23769875. 
Bartoli P, Boudouresque C. Effect of the digenean parasites of fish on the fauna of Mediterranean lagoons. Parassitologia 2007; 49(3): 111-117. PMid:18410068.

Belo MAA, Souza DGF, Faria VP, Prado EJR, Moraes FR, Onaka EM. Haematological response of curimbas Prochilodus lineatus, naturally infected with Neoechinorhynchus curemai. J Fish Biol 2013; 82(4): 14031410. http://dx.doi.org/10.1111/jfb.12060. PMid:23557315.

Bianchi ME. DAMPs, PAMPs and alarmins: all we need to know about danger. J Leukoc Biol 2007; 81(1): 1-5. http://dx.doi.org/10.1189/ jlb.0306164. PMid:17032697.

Bondad-Reantaso MG, Ogawa K, Yoshinaga T, Wakabayashi H. Acquired protection against Neobenedenia girellae in Japanese flounder. Fish Pathol 1995; 30(3): 233-238. http://dx.doi.org/10.3147/jsfp.30.233.

Bosi G, Shinn AP, Giari L, Simoni E, Pironi F, Dezfuli BS. Changes in the neuromodulators of the diffuse endocrine system of the alimentary canal of farmed rainbow trout, Oncorhynchus mykiss (Walbaum), naturally infected with Eubothrium crassum (Cestoda). J Fish Dis 2005; 28(12): 703-711. http://dx.doi.org/10.1111/j.1365-2761.2005.00674.x. PMid:16336471.

Bowden TJ, Cook P, Rombout JHWM. Development and function of the thymus in teleosts. Fish Shellfish Immunol 2005; 19(5): 413-427. http:// dx.doi.org/10.1016/j.fsi.2005.02.003. PMid:15893472.

Bowden TJ. Modulation of the immune system of fish by their environment. Fish Shellfish Immunol 2008; 25(4): 373-383. http://dx.doi.org/10.1016/j. fsi.2008.03.017. PMid:18562213.

Bromage ES, Kaattari IM, Zwollo P, Kaattari SL. Plasmablast and plasma cell production and distribution in trout immune tissues. J Immunol 2004; 173(12): 7317-7323. http://dx.doi.org/10.4049/jimmunol.173.12.7317. PMid:15585855.

Buchmann K, Lindenstrøm T. Interactions between monogenean parasites and their fish hosts. Int J Parasitol 2002; 32(3): 309-319. http://dx.doi. org/10.1016/S0020-7519(01)00332-0. PMid:11835971.

Buchmann K, Mehrdana F. Effects of anisakid nematodes Anisakis simplex (s.l.), Pseudoterranova decipiens (s.l.) and Contracaecum osculatum (s.l.) on fish and consumer health. Food Waterborne Parasitol 2016; 4: 13-22. http://dx.doi.org/10.1016/j.fawpar.2016.07.003.

Buchmann K, Pedersen LØ, Glamann J. Humoral immune response of European eel Anguilla anguilla to a major antigen in Anguillicola crassus (Nematoda). Dis Aquat Organ 1991; 12(1): 55-57.

Buchmann K. Binding and lethal effect of complement from Oncorhynchus mykiss on Gyrodactylus derjavini (Platyhelminthes: monogenea). Dis Aquat Organ 1998; 32(3): 195-200. http://dx.doi.org/10.3354/dao032195. PMid:9676245.

Cai XQ, Xu MJ, Wang YH, Qiu DY, Liu GX, Lin A, et al. Sensitive and rapid detection of Clonorchis sinensis infection in fish by loop-mediated isothermal amplification (LAMP). Parasitol Res 2010; 106(6): 13791383. http://dx.doi.org/10.1007/s00436-010-1812-3. PMid:20232082.

Cammilleri G, Chetta M, Costa A, Graci S, Collura R, Buscemi MD, et al. Validation of the TrichinEasy ${ }^{\circledR}$ digestion system for the detection of Anisakidae larvae in fish products. Acta Parasitol 2016; 61(2): 369-375. http://dx.doi.org/10.1515/ap-2016-0048. PMid:27078661.

Campos CM, Moraes JR, Moraes EFR. Histopatologia de fígado, rim e baço de Piaractus mesopotamicus, Prochilodus lineatus e Pseudoplatystoma fasciatum parasitados por myxosporídios, capturados no Rio Aquidauana, Mato Grosso do Sul, Brasil. Rev Bras Parasitol Vet 2008; 17(4): 200-205. http://dx.doi.org/10.1590/S1984-29612008000400006. PMid:19265578.
Cavalcanti ETS, Takemoto RM, Alves LC, Chellappa S. First report of metazoan fish parasites with zoonotic potential in Scomberomorus brasiliensis and Trichiurus lepturus from the coastal waters of Rio Grande do Norte, Brazil. Mar Biodivers Rec 2012; 5: e40. http://dx.doi.org/10.1017/ S1755267212000292.

Chai J-Y, Darwin Murrell K, Lymbery AJ. Fish-borne parasitic zoonoses: status and issues. Int J Parasitol 2005; 35(11-12): 1233-1254. http:// dx.doi.org/10.1016/j.ijpara.2005.07.013. PMid:16143336.

Constenla $M$, Carrassón $M$, Moyà $C M$, Fernàndez-Chacón A, Padrós F, Repullés-Albelda A, et al. Parasitisation by Bathycreadium elongatum (Digenea, Opecoelidae) in pyloric caeca of Trachyrincus scabrus (Teleostei, Macrouridae). Dis Aquat Organ 2011; 96(3): 239-247. http://dx.doi. org/10.3354/dao02393. PMid:22132502.

Cooper MD, Alder MN. The evolution of adaptive immune systems. Cell 2006; 124(4): 815-822. http://dx.doi.org/10.1016/j.cell.2006.02.001. PMid:16497590.

Coscia MR, Oreste U. Presence of antibodies specific for proteins of Contracaecum osculatum (Rudolphi, 1908) in plasma of several Antarctic teleosts. Fish Shellfish Immunol 1998; 8(4): 295-302. http://dx.doi. org/10.1006/fsim.1998.0140.

Coscia MR, Oreste U. Plasma and bile antibodies of the teleost Trematomus bernacchii specific for the nematode Pseudoterranova decipiens. Dis Aquat Organ 2000; 41(1): 37-42. http://dx.doi.org/10.3354/dao041037. PMid:10907137.

Costa MM, Maehr T, Diaz-Rosales P, Secombes CJ, Wang T. Bioactivity studies of rainbow trout (Oncorhynchus mykiss) interleukin-6: effects on macrophage growth and antimicrobial peptide gene expression. Mol Immunol 2011; 48(15-16): 1903-1916. http://dx.doi.org/10.1016/j. molimm.2011.05.027. PMid:21704380.

Costa OTF, Dias LC, Malmann CSY, Lima Ferreira CA, Carmo IB, Wischneski AG, et al. The effects of stocking density on the hematology, plasma protein profile and immunoglobulin production of juvenile tambaqui (Colossoma macropomum) farmed in Brazil. Aquaculture 2019; 499: 260-268. http://dx.doi.org/10.1016/j.aquaculture.2018.09.040.

Danilova N, Bussmann J, Jekosch K, Steiner LA. The immunoglobulin heavy-chain locus in zebrafish: identification and expression of a previously unknown isotype, immunoglobulin Z. Nat Immunol 2005; 6(3): 295302. http://dx.doi.org/10.1038/ni1166. PMid:15685175.

Decostere A, Haesebrouck F, Turnbull JF, Charlier G. Influence of water quality and temperature on adhesion of high and low virulence Flavobacterium columnare strains to isolated gill arches. J Fish Dis 1999; 22(1): 1-11. http://dx.doi.org/10.1046/j.1365-2761.1999.00132.x.

Dezfuli BS, Lui A, Boldrini P, Pironi F, Giari L. The inflammatory response of fish to helminth parasites. Parasite 2008; 15(3): 426-433. http://dx.doi.org/10.1051/parasite/2008153426. PMid:18814717.

Dezfuli BS, Pironi F, Shinn AP, Manera M, Giari L. Histopathology and ultrastructure of Platichthys flesus naturally infected with Anisakis simplex s.l. larvae (Nematoda: anisakidae). J Parasitol 2007; 93(6): 1416-1423. http://dx.doi.org/10.1645/GE-1214.1. PMid:18314688.

Dezfuli BS, Pironi F, Giari L, Noga EJ. Immunocytochemical localization of piscidin in mast cells of infected seabass gill. Fish Shellfish Immunol 2010a; 28(3): 476-482. http://dx.doi.org/10.1016/j.fsi.2009.12.012. PMid:20034572.

Dezfuli BS, Pironi F, Campisi M, Shinn AP, Giari L. The response of intestinal mucous cells to the presence of enteric helminths: their distribution, 
histochemistry and fine structure. J Fish Dis 2010b; 33(6): 481-488. http://dx.doi.org/10.1111/j.1365-2761.2010.01146.x. PMid:20298449.

Dezfuli BS, Giari L, Squerzanti S, Lui A, Lorenzoni M, Sakalli S, et al. Histological damage and inflammatory response elicited by Monobothrium wageneri (Cestoda) in the intestine of Tinca tinca (Cyprinidae). Parasit Vectors 2011; 4(1): 225. http://dx.doi.org/10.1186/1756-3305-4-225. PMid:22152408.

Dezfuli BS, Giari L, Lui A, Squerzanti S, Castaldelli G, Shinn AP, et al. Proliferative cell nuclear antigen (PCNA) expression in the intestine of Salmo trutta trutta naturally infected with an acanthocephalan. Parasit Vectors 2012; 5(1): 198. http://dx.doi.org/10.1186/1756-3305-5-198. PMid:22967751.

Dezfuli BS, Lui A, Pironi F, Manera M, Shinn AP, Lorenzoni M. Cell types and structures involved in tench, Tinca tinca (L.), defence mechanisms against a systemic digenean infection. J Fish Dis 2013; 36(6): 577-585. http://dx.doi.org/10.1111/jfd.12049. PMid:23294469.

Dezfuli BS, Bo T, Lorenzoni M, Shinn AP, Giari L. Fine structure and cellular responses at the host-parasite interface in a range of fish-helminth systems. Vet Parasitol2015; 208(3-4): 272-279. http://dx.doi.org/10.1016/j. vetpar.2015.01.002. PMid:25613477.

Dezfuli BS, Bosi G, DePasquale JA, Manera M, Giari L. Fish innate immunity against intestinal helminths. Fish Shellfish Immunol 2016; 50: 274-287. http://dx.doi.org/10.1016/j.fsi.2016.02.002. PMid:26868213.

Dezfuli BS, DePasquale JA, Castaldelli G, Giari L, Bosi G. A fish model for the study of the relationship between neuroendocrine and immune cells in the intestinal epithelium: silurus glanis infected with a tapeworm. Fish Shellfish Immunol 2017; 64: 243-250. http://dx.doi.org/10.1016/j. fsi.2017.03.033. PMid:28330806.

Dezfuli BS, Giari L, Lorenzoni M, Carosi A, Manera M, Bosi G. Pike intestinal reaction to Acanthocephalus lucii (Acanthocephala): immunohistochemical and ultrastructural surveys. Parasit Vectors 2018; 11(1): 424. http://dx.doi. org/10.1186/s13071-018-3002-6. PMid:30012189.

Edholm ES, Bengtén E, Stafford JL, Sahoo M, Taylor EB, Miller $\mathrm{NW}$, et al. Identification of two $\mathrm{IgD}+\mathrm{B}$ cell populations in channel catfish, Ictalurus punctatus. J Immunol 2010; 185(7): 4082-4094. http:// dx.doi.org/10.4049/jimmunol.1000631. PMid:20817869.

Ehlers U. Comments on a phylogenetic system of the Platyhelminthes. Hydrobiologia 1986; 132(1): 1-12. http://dx.doi.org/10.1007/BF00046222.

Eiras JC, Pavanelli GC, Takemoto RM, Nawa Y. Fish-borne nematodiases in South America: neglected emerging diseases. J Helminthol 2018; 92(6): 649-654. http://dx.doi.org/10.1017/S0022149X17001006. PMid:29067898.

El Deen AIN, Zaki MS, Fawzi OM. New diagnostic methods of parasitic infections in freshwater fishes. J Adv Pharm Educ Res 2018; 8(1): 96-102.

Faliex E, Silva C, Simon G, Sasal P. Dynamic expression of immune response genes in the sea bass, Dicentrarchus labrax, experimentally infected with the monogenean Diplectanum aequans. Fish Shellfish Immunol 2008; 24(6): 759-767. http://dx.doi.org/10.1016/j.fsi.2008.02.011. PMid:18396061.

Fischer C, Malta JCO, Varella AMB. The fauna of parasites of the tambaqui, Colossoma macropomum (Cuvier, 1818)(Characiformes: Characidae) from middle Solimóes River and lower Amazonas River and their potential as biological indicators. Acta Amazon 2003; 33(4): 651-662. http://dx.doi. org/10.1590/S0044-59672003000400012.

Flajnik MF, Kasahara M. Origin and evolution of the adaptive immune system: genetic events and selective pressures. Nat Rev Genet 2010; 11(1): 47-59. http://dx.doi.org/10.1038/nrg2703. PMid:19997068.
Gaines APL, Lozano LES, Viana GM, Monteiro PC, Araújo CSO. Tissue changes in the gut of Arapaima gigas (Schinz, 1822), infected by the nematode Spirocamallanus inopinatus (Travassos, 1929). Neotrop Helminthol 2012; 6(2): 147-157.

Gamboa PM, Asturias J, Martínez R, Antépara I, Jáuregui I, Urrutia $\mathrm{I}$, et al. Diagnostic utility of components in allergy to Anisakis simplex. J Investig Allergol Clin Immunol 2012; 22(1): 13-19. PMid:22448449.

Ghosh J, Lun CH, Majeske AJ, Sacchi S, Schrankel CS, Smith LC. Invertebrate immune diversity. Dev Comp Immunol 2011; 35(9): 959974. http://dx.doi.org/10.1016/j.dci.2010.12.009. PMid:21182860.

Gómez GD, Balcázar JL. A review on the interactions between gut microbiota and innate immunity of fish. FEMS Immunol Med Microbiol 2008; 52(2): 145-154. http://dx.doi.org/10.1111/j.1574-695X.2007.00343.x. PMid:18081845.

Grobbelaar A, van As LL, van As JG, Butler HJB. Pathology of eyes and brain of fish infected with diplostomids, southern Africa. Afr Zool 2015; 50(2): 181-186. http://dx.doi.org/10.1080/15627020.2015.1055701.

Haarder S, Kania PW, Bahlool QZ, Buchmann K. Expression of immune relevant genes in rainbow trout following exposure to live Anisakis simplex larvae. Exp Parasitol2013; 135(3): 564-569. http://dx.doi.org/10.1016/j. exppara.2013.09.011. PMid:24051344.

Harris JE. The immune response of a Cyprinid fish to infections of the acanthocephalan Pomphorhynchus laevis. Int J Parasitol 1972; 2(4): 459469. http://dx.doi.org/10.1016/0020-7519(72)90091-4. PMid:4196350.

Harris NL, Loke P. Recent advances in type-2-cell-mediated immunity: insights from helminth infection. Immunity 2017; 47(6): 1024-1036. http://dx.doi.org/10.1016/j.immuni.2017.11.015. PMid:29262347.

Harris PD, Soleng A, Bakke TA. Killing of Gyrodactylus salaris (Platyhelminthes, Monogenea) mediated by host complement. Parasitology 1998; 117(Pt2): 137-143. http://dx.doi.org/10.1017/S003118209800287X. PMid:9778636.

Hatanaka A, Umeda N, Yamashita S, Hirazawa N. A small ciliary surface glycoprotein of the monogenean parasite Neobenedenia girellae acts as an agglutination/immobilization antigen and induces an immune response in the Japanese flounder Paralichthys olivaceus. Parasitology 2005; 131(Pt5): 591-600. http://dx.doi.org/10.1017/S0031182005008322. PMid:16255817.

Heuch PA, Jansen PA, Hansen H, Sterud E, MacKenzie K, Haugen P, et al. Parasite faunas of farmed cod and adjacent wild cod populations in Norway: a comparison. Aquacult Environ Interact 2011; 2(1): 1-13. http://dx.doi.org/10.3354/aei00027.

Hirazawa N, Ishizuka R, Hagiwara H. The effects of Neobenedenia girellae (Monogenea) infection on host amberjack Seriola dumerili (Carangidae): hematological and histopathological analyses. Aquaculture 2016; 461: 32-39. http://dx.doi.org/10.1016/j.aquaculture.2016.04.007.

Höglund J, Thuvander A. Indications of non-specific protective mechanisms in rainbow trout Oncorhynchus mykiss with diplostomosis. Dis Aquat Organ 1990; 8(2): 91-97. http://dx.doi.org/10.3354/dao008091.

Höglund J, Pilström L. Purification of adult Anguillicola crassus wholeworm extract antigens for detection of specific antibodies in serum from the European eel (Anguilla anguilla) by ELISA. Fish Shellfish Immunol 1994; 4(4): 311-319. http://dx.doi.org/10.1006/fsim.1994.1027.

Hoshino MDFG, Neves LR, Tavares-Dias M. Parasite communities of the predatory fish, Acestrorhynchus falcatus and Acestrorhynchus falcirostris, living in sympatry in Brazilian Amazon. Rev Bras Parasitol Vet 2016; 25(2): 207-216. http://dx.doi.org/10.1590/S1984-29612016038. PMid:27334822. 
Hung N, Madsen H, Fried B. Global status of fish-borne zoonotic trematodiasis in humans. Acta Parasitol 2013; 58(3): 231-258. http:// dx.doi.org/10.2478/s11686-013-0155-5. PMid:23990419.

Jaiswal N, Tripathi R, Malhotra SK. Accentuated molecular detection technique to segregate and identify helminths of fish through High Resolution Melting (HRM) Analysis. Single Cell Biol 2017; 6(02): 2. http://dx.doi.org/10.4172/2168-9431.1000163.

Jerônimo GT, Pádua SB, Belo MAA, Chagas EC, Taboga SR, Maciel PO, et al. Neoechinorhynchus buttnerae (Acanthocephala) infection in farmed Colossoma macropomum: A pathological approach. Aquaculture 2017; 469: 124-127. http://dx.doi.org/10.1016/j.aquaculture.2016.11.027.

Jones JDG, Dangl JL. The plant immune system. Nature 2006; 444(7117): 323-329. http://dx.doi.org/10.1038/nature05286. PMid:17108957.

Karvonen A, Hudson PJ, Seppälä O, Valtonen ET. Transmission dynamics of a trematode parasite: exposure, acquired resistance and parasite aggregation. Parasitol Res 2004; 92(3): 183-188. http://dx.doi. org/10.1007/s00436-003-1035-y. PMid:14652746.

Kishimori JM, Takemura A, Leong JAC. Neobenedenia melleni-specific antibodies are associated with protection after continuous exposure in Mozambique Tilapia. J Immunol Res 2015; 2015: 635387. http://dx.doi. org/10.1155/2015/635387. PMid:25756055.

Knopf K, Lucius R. Vaccination of eels (Anguilla japonica and Anguilla anguilla) against Anguillicola crassus with irradiated L 3. Parasitology 2008; 135(5): 633-640. http://dx.doi.org/10.1017/S0031182008004162. PMid:18302804.

Kotob MH, Menanteau-Ledouble S, Kumar G, Abdelzaher M, ElMatbouli M. The impact of co-infections on fish: a review. Vet Res (Faisalabad) 2017; 47(1): 98. http://dx.doi.org/10.1186/s13567-0160383-4. PMid:27716438.

Kumar S, Raman RP, Prasad KP, Srivastava PP, Kumar S, Rajendran $\mathrm{KV}$. Effects on haematological and serum biochemical parameters of Pangasianodon hypophthalmus to an experimental infection of Thaparocleidus sp. (Monogenea: dactylogyridae). Exp Parasitol 2018; 188: 1-7. http:// dx.doi.org/10.1016/j.exppara.2018.02.007. PMid:29501694.

Kundu I, Bandyopadhyay PK, Mandal DR, Gürelli G. Study of pathophysiological effects of the nematode parasite Eustrongylides sp. on Freshwater fish Channa punctatus by hematology, serum biochemical, and histological studies. Turkiye Parazitol Derg 2016; 40(1): 42-47. http:// dx.doi.org/10.5152/tpd.2016.4551. PMid:27222335.

Leung TL, Bates AE. More rapid and severe disease outbreaks for aquaculture at the tropics: implications for food security. J Appl Ecol 2013; 50(1): 215-222. http://dx.doi.org/10.1111/1365-2644.12017.

Li WX, Zou H, Wu SG, Xiong F, Li M, Ma XR, et al. Composition and diversity of communities of Dactylogyrus spp. in wild and farmed goldfish Carassius auratus. J Parasitol 2018; 104(4): 353-358. http:// dx.doi.org/10.1645/16-192. PMid:29648929.

Lieschke GJ, Trede NS. Fish immunology. Curr Biol 2009; 19(16): R678-R682. http://dx.doi.org/10.1016/j.cub.2009.06.068. PMid:19706273.

Lugo-Villarino G, Balla KM, Stachura DL, Bañuelos K, Werneck MBF, Traver D. Identification of dendritic antigen-presenting cells in the zebrafish. Proc Natl Acad Sci USA 2010; 107(36): 15850-15855. http:// dx.doi.org/10.1073/pnas.1000494107. PMid:20733076.

Luque JL. Biologia, epidemiologia e controle de parasitos de peixes. Rev Bras Parasitol Vet 2004; 13(Suppl 1): 161-165.
Magnadóttir B. Innate immunity of fish (overview). Fish Shellfish Immunol 2006; 20(2): 137-151. http://dx.doi.org/10.1016/j.fsi.2004.09.006. PMid:15950491.

Magnadóttir B. Immunological control of fish diseases. Mar Biotechnol (NY) 2010; 12(4): 361-379. http://dx.doi.org/10.1007/s10126-0109279-x. PMid:20352271.

Malta JCO, Gomes ALS, Andrade SMS, Varella AMB. Infestaçóes maciças por acantocéfalos, Neoechinorhynchus buttnerae Golvan, 1956, (Eoacanthocephala: Neoechinorhynchidae) em tambaquis jovens, Colossoma macropomum (Cuvier, 1818) cultivados na Amazônia Central. Acta Amazon 2001; 31(1): 133-143. http://dx.doi.org/10.1590/180943922001311143.

Marinho RGB, Tostes LV, Borges M, Oba-Yoshioka ET, Tavares-Dias M. Respostas hematológicas de Arapaima gigas (Pisces: Arapaimidae) parasitados naturalmente por protozoários e metazoários. Biota Amazôn 2015; 5(1): 105-108. http://dx.doi.org/10.18561/2179-5746/biotaamazonia. v5n1p105-108.

Martin SAM, Król E. Nutrigenomics and immune function in fish: new insights from omics technologies. Dev Comp Immunol 2017; 75: 86-98. http://dx.doi.org/10.1016/j.dci.2017.02.024. PMid:28254621.

Martins ML, Moraes FR, Fujimoto RY, Onaka EM, Quintana CIF. Prevalence and histopathology of Neoechinorhynchus curemai Noronha, 1973 (Acanthocephala: Neoechinorhynchidae) in Prochilodus lineatus Valenciennes, 1836 from Volta Grande Reservoir, MG, Brazil. Braz J Biol 2001; 61(3): 517-522. http://dx.doi.org/10.1590/S151969842001000300022. PMid:11706580.

Martins ML, Tavares-Dias M, Janik AJ, Kent ML, Jerônimo GT. Hematology and condition factor of tui chub and fathead minnow parasitized by nematode from Upper Klamath Lake, Oregon, USA. Dis Aquat Organ 2017; 126(3): 257-262. http://dx.doi.org/10.3354/ dao03168. PMid:29160223.

Mashoof S, Criscitiello MF. Fish immunoglobulins. Biology (Basel) 2016; 5(4): 45. http://dx.doi.org/10.3390/biology5040045. PMid:27879632.

Matos LV, Oliveira MIB, Gomes ALS, Silva GS. Morphological and histochemical changes associated with massive infection by Neoechinorhynchus buttnerae (Acanthocephala: Neoechinorhynchidae) in the farmed freshwater fish Colossoma macropomum Cuvier, 1818 from the Amazon State, Brazil Parasitol Res 2017; 116(3): 1029-1037. http://dx.doi.org/10.1007/ s00436-017-5384-3. PMid:28124738.

Matsuyama T, Fujiwara A, Nakayasu C, Kamaishi T, Oseko N, Tsutsumi N, et al. Microarray analyses of gene expression in Japanese flounder Paralichthys olivaceus leucocytes during monogenean parasite Neoheterobothrium hirame infection. Dis Aquat Organ 2007; 75(1): 79-83. http://dx.doi.org/10.3354/dao075079. PMid:17523546.

Mazur OE, Tolochko LV. Cytomorphological and biochemical characteristics of the whitefish, Baikal omul Coregonus migratorius, infected by plerocercoids of Diphyllobothrium dendriticum (Cestoda: pseudophyllidae). Biol Bull 2015; 42(2): 117-123. http://dx.doi.org/10.1134/S1062359015020065. PMid:26021157.

Mazzanti C, Monni G, Cognetti V. Observations on antigenic activity of Pseudodactylogyrus anguillae (Monogenea) on the European eel (Anguilla anguilla). Bull Eur Assoc Fish Pathol 1999; 19(2): 57-59.

McArthur CP. Humoral antibody production by New Zealand eels, against the intestinal trematode Telogaster opisthorchis Macfarlane, 1945. J Fish Dis 1978; 1(4): 377-387. http://dx.doi.org/10.1111/j.1365-2761.1978. tb00042.x. 
Mdegela RH, Omary AN, Mathew C, Nonga HE. Effect of pond management on prevalence of intestinal parasites in Nile tilapia (Oreochromis niloticus) under small scale fish farming systems in Morogoro, Tanzania. Livest Res Rural Dev 2011; 23(6): 127.

Melo FTV, Rodrigues RAR, Giese EG, Gardner SL, Santos JN. Histopathologic aspects in Plagioscion squamosissimus (HECKEL, 1940) induced by Neoechinorhynchus veropesoi, metacestodes and anisakidae juveniles. Rev Bras Parasitol Vet 2014; 23(2): 224-230. http://dx.doi. org/10.1590/S1984-29612014048. PMid:25054502.

Mladineo I, Block BA. Expression of cytokines IL-1 $\beta$ and TNF- $\alpha$ in tissues and cysts surrounding Didymocystis wedli (Digenea, Didymozoidae) in the Pacific bluefin tuna (Thunnus orientalis). Fish Shellfish Immunol 2010; 29(3): 487-493. http://dx.doi.org/10.1016/j.fsi.2010.05.008. PMid:20580835.

Mladineo I, Zrnčić S, Oraić D. Severe helminthic infection of the wild brown trout (Salmo trutta) in Cetina River, Croatia. Bull Eur Assoc Fish Pathol 2009; 29(3): 86-91.

Molnár K, Majoros G, Csaba G, Székely C. Pathology of Atractolytocestus huronensis Anthony, 1958 (Cestoda, Caryophyllaeidae) in Hungarian pond-farmed common carp. Acta Parasitol 2003; 48(3): 222-228.

Molnár K. Histopathological changes caused by the metacestodes of Neogryporhynchus cheilancristrotus (Wedl, 1855) in the gut of the gibel carp, Carassius gibelio. Acta Vet Hung 2005; 53(1): 45-52. http://dx.doi. org/10.1556/AVet.53.2005.1.5. PMid:15782658.

Morley NJ, Hoole D. Ultrastructural studies on the host-parasite interface between Khawia sinensis (Cestoda: Caryophyllidea) and carp Cyprinus carpio. Dis Aquat Organ 1995; 23(2): 93-99. http://dx.doi.org/10.3354/ dao023093.

Nazir S, Ali MN, Chishti MZ. Purification and Characterization of Pomphorhynchus kashmirensis Somatic Antigens Collected from Naturally Infected Local Fish Schizothorax. NY Sci J 2013; 6(7): 24-28.

Nie P, Hoole D. Antibody response of carp, Cyprinus carpio to the cestode, Bothriocephalus acheilognathi. Parasitology 1999; 118(6): 635-639. http:// dx.doi.org/10.1017/S0031182099004242. PMid:10406042.

Nielsen ME, Buchmann K. Glutathione-s-transferase is an important antigen in the eel nematode Anguillicola crassus. J Helminthol 1997; 71(4): 319-324. http://dx.doi.org/10.1017/S0022149X00016138. PMid:9443950.

Oba ET, Mariano WS, Santos LRB. Estresse em peixes cultivados: agravantes e atenuantes para o manejo rentável. In: Tavares-Dias M. Manejo e sanidade de peixes em cultivo. Macapá: Embrapra; 2009. p. 226-247.

Ogawa K. Diseases of cultured marine fishes caused by Platyhelminthes (Monogenea, Digenea, Cestoda). Parasitology 2015; 142(1): 178-195. http://dx.doi.org/10.1017/S0031182014000808. PMid:24998438.

Olabuenaga SE. Sistema inmune en peces. Gayana (Concepc) 2000; 64(2): 205-215. http://dx.doi.org/10.4067/S0717-65382000000200010.

Polinski M, Shirakashi S, Bridle A, Nowak B. Transcriptional immune response of cage-cultured Pacific bluefin tuna during infection by two Cardicola blood fluke species. Fish Shellfish Immunol 2014; 36(1): 61-67. http://dx.doi.org/10.1016/j.fsi.2013.10.008. PMid:24161760.

Press CM, Evensen $\varnothing$. The morphology of the immune system in teleost fishes. Fish Shellfish Immunol 1999; 9(4): 309-318. http://dx.doi. org/10.1006/fsim.1998.0181.
Priebe K, Huber C, Märtlbauer E, Terplan G. Detection of antibodies against the larva of Anisakis simplex in the pollock Pollachius virens using ELISA. Zentralbl Veterinärmed B 1991; 38(3): 209-214. PMid:1858459.

Pylkkö P, Suomalainen LR, Tiirola M, Valtonen ET. Evidence of enhanced bacterial invasion during Diplostomum spathaceum infection in European grayling, Thymallus thymallus (L.). J Fish Dis 2006; 29(2): 79-86. http:// dx.doi.org/10.1111/j.1365-2761.2006.00683.x. PMid:16436118.

Rauta PR, Nayak B, Das S. Immune system and immune responses in fish and their role in comparative immunity study: a model for higher organisms. Immunol Lett 2012; 148(1): 23-33. http://dx.doi.org/10.1016/j. imlet.2012.08.003. PMid:22902399.

Reite OB, Evensen $\varnothing$. Inflammatory cells of teleostean fish: a review focusing on mast cells/eosinophilic granule cells and rodlet cells. Fish Shellfish Immunol 2006; 20(2): 192-208. http://dx.doi.org/10.1016/j. fsi.2005.01.012. PMid:15978838.

Reyes-Becerril M, Alamillo E, Trasviña A, Hirono I, Kondo H, Jirapongpairoj W, et al. In vivo and in vitro studies using larval and adult antigens from Neobenedenia melleni on immune response in yellowtail (Seriola lalandi). J Fish Dis 2017; 40(11): 1497-1509. http://dx.doi. org/10.1111/jfd.12620. PMid:28422295.

Roberts ML, Lewis JW, Wiegertjes GF, Hoole D. Interaction between the blood fluke, Sanguinicola inermis and humoral components of the immune response of carp, Cyprinus carpio. Parasitology 2005; 131(2): 261271. http://dx.doi.org/10.1017/S0031182005007651. PMid:16145943.

Rocha MJS, Jerônimo GT, Costa OTFD, Malta JCO, Martins ML, Maciel PO, et al. Changes in hematological and biochemical parameters of tambaqui (Colossoma macropomum) parasitized by metazoan species. Rev Bras Parasitol Vet 2018; 27(4): 488-494. http://dx.doi.org/10.1590/ s1984-296120180073. PMid:30427527.

Rodrigues MV, Pantoja JCF, Guimarães CDO, Benigno RNM, Palha MDC, Biondi GF. Prevalence for nematodes of hygiene-sanitary importance in fish from Colares Island and Vigia, Pará, Brasil. Rev Bras Cienc Vet 2015; 22(2): 124-128. http://dx.doi.org/10.4322/rbcv.2015.364.

Rombout JHWM, Abelli L, Picchietti S, Scapigliati G, Kiron V. Teleost intestinal immunology. Fish Shellfish Immunol 2011; 31(5): 616-626. http://dx.doi.org/10.1016/j.fsi.2010.09.001. PMid:20832474.

Rombout JHWM, Yang G, Kiron V. Adaptive immune responses at mucosal surfaces of teleost fish. Fish Shellfish Immunol 2014; 40(2): 634-643. http://dx.doi.org/10.1016/j.fsi.2014.08.020. PMid:25150451.

Roon SR, Alexander JD, Jacobson KC, Bartholomew JL. Effect of Nanophyetus salmincola and bacterial co-infection on mortality of juvenile Chinook Salmon. J Aquat Anim Health 2015; 27(4): 209-216. http:// dx.doi.org/10.1080/08997659.2015.1094150. PMid:26671546.

Rubio-Godoy M, Sigh J, Buchmann K, Tinsley RC. Antibodies against Discocotyle sagittata (Monogenea) in farmed trout. Dis Aquat Organ 2003; 56(2): 181-184. http://dx.doi.org/10.3354/dao056181. PMid:14598994.

Salinas I, Zhang YA, Sunyer JO. Mucosal immunoglobulins and B cells of teleost fish. Dev Comp Immunol 2011; 35(12): 1346-1365. http:// dx.doi.org/10.1016/j.dci.2011.11.009. PMid:22133710.

Salvador R, Muller EE, Leonhardt JH, Pretto-Giordano LG, Dias JA, Freitas JC, et al. Isolamento de Streptococcus spp. de tilápias do Nilo (Oreochromis niloticus) e qualidade da água de tanques rede na Região Norte do Estado do Paraná, Brasil. Semina: Ciênc Agrár 2003; 24(1): 35-42. http://dx.doi.org/10.5433/1679-0359.2003v24n1p35.

Sandoval-Gío JJ, Rodríguez-Canul R, Vidal-Martínez VM. Humoral antibody response of the tilapia Oreochromis niloticus against Cichlidogyrus 
spp. (Monogenea). J Parasitol 2008; 94(2): 404-409. http://dx.doi. org/10.1645/GE-1382.1. PMid:18564741.

Santos RBS, Tavares-Dias M. Células sanguíneas e resposta hematológica de Oxydoras niger (Pisces, Doradidae) oriundos da bacia do médio Rio Solimóes, estado do Amazonas (Brasil), naturalmente parasitados. Bol Inst Pesca 2010; 36(4): 283-292.

Schmidt-Posthaus H, Steiner P, Müller B, Casanova-Nakayama A. Complex interaction between proliferative kidney disease, water temperature and concurrent nematode infection in brown trout. Dis Aquat Organ 2013; 104(1): 23-34. http://dx.doi.org/10.3354/dao02580. PMid:23670077.

Secombes CJ, Wang T, Hong S, Peddie S, Crampe M, Laing KJ, et al. Cytokines and innate immunity of fish. Dev Comp Immunol 2001; 25(8-9): 713-723. http://dx.doi.org/10.1016/S0145-305X(01)00032-5. PMid:11602192.

Secombes CJ, Wang T. The innate and adaptive immune system of fish. In: Austin B. Infectious diseases in aquaculture: prevention and control. Cambridge: Woodhead Publishing; 2012. p. 3-68. http://dx.doi. org/10.1533/9780857095732.1.3.

Secombes CJ. The nonspecific immune system: cellular defenses. In: Iwama G, Nakanishi T. The fish immune system: organism, pathogen and environment. San Diego: Academic Press; 1996. p. 63-103. http://dx.doi. org/10.1016/S1546-5098(08)60272-1.

Shah AW, Parveen M, Mir SH, Sarwar SG, Yousuf AR. Impact of helminth parasitism on fish haematology of Anchar Lake, Kashmir. Pak J Nutr 2009; 8(1): 42-45. http://dx.doi.org/10.3923/pjn.2009.42.45.

Sharp GJE, Pike AW, Secombes CJ. The immune response of wild rainbow trout, Salmo gairdneri Richardson, to naturally acquired plerocercoid infections of Diphyllobothrium dendriticum (Nitzsch, 1824) and D. ditremum (Creplin, 1825). J Fish Biol 1989; 35(6): 781-794. http://dx.doi.org/10.1111/j.1095-8649.1989.tb03029.x.

Sharp GJE, Pike AW, Secombes CJ. Sequential development of the immune response in rainbow trout [Oncorhynchus mykiss (Walbaum, 1792)] to experimental plerocercoid infections of Diphyllobothrium dendriticum (Nitzsch, 1824). Parasitology 1992; 104(1): 169-178. http:// dx.doi.org/10.1017/S0031182000060911. PMid:1614733.

Sitjà-Bobadilla A. Living off a fish: a trade-off between parasites and the immune system. Fish Shellfish Immunol 2008; 25(4): 358-372. http:// dx.doi.org/10.1016/j.fsi.2008.03.018. PMid:18722790.

Slotved HC, Buchmann K. Acquired resistance of the eel, Anguilla anguilla L., to challenge infections with gill monogeneans. J Fish Dis 1993; 16(6): 585-591. http://dx.doi.org/10.1111/j.1365-2761.1993.tb00895.x.

Sripa B, Kaewkes S, Sithithaworn P, Mairiang E, Laha T, Smout M, et al. Liver fluke induces cholangiocarcinoma. PLoS Med 2007; 4(7): e201. http://dx.doi.org/10.1371/journal.pmed.0040201. PMid:17622191.

Sripa B, Kaewkes S, Intapan PM, Maleewong W, Brindley PJ. Foodborne trematodiases in Southeast Asia: epidemiology, pathology, clinical manifestation and control. Adv Parasitol 2010; 72: 305-350. http://dx.doi. org/10.1016/S0065-308X(10)72011-X. PMid:20624536.

Stables JN, Chappell LH. Putative immune response of rainbow trout, Salmo gairdneri, to Diplostomum spathaceum infections. J Fish Biol 1986; 29(1): 115-122. http://dx.doi.org/10.1111/j.1095-8649.1986.tb04931.x.

Szalai AJ, Danell GV, Dick TA. Intestinal leakage and precipitating antibodies in the serum of quillback, Carpiodes cyprinus (Lesueur), infected with Neoechinorhynchus carpiodi Dechtiar, 1968 (Acanthocephala: neoechinorhynchidae). J Parasitol 1988; 74(3): 415-420. http://dx.doi. org/10.2307/3282048.
Szwejser E, Verburg-van Kemenade BML, Maciuszek M, Chadzinska M. Estrogen-dependent seasonal adaptations in the immune response of fish. Horm Behav 2017; 88: 15-24. http://dx.doi.org/10.1016/j. yhbeh.2016.10.007. PMid:27760301.

Tavares-Dias M, Martins ML. An overall estimation of losses caused by diseases in the Brazilian fish farms. J Parasit Dis 2017; 41(4): 913-918. http://dx.doi.org/10.1007/s12639-017-0938-y. PMid:29114119.

Tavares-Dias M, Moraes FR, Martins ML. Hematological assessment in four Brazilian teleost fish with parasitic infections, collected in feefishing from Franca, São Paulo, Brazil. Bol Inst Pesca 2008; 34(2): 189-196.

Thatcher VE. The isopod parasites of South American fishes. In: SalgadoMaldonado G, Garcia Aldrete AN, Vidal-Martinez VM. Metazoan in the neotropics: a systematic and ecological perspective. México: Instituto de Biología de la Universidad Nacional Autónoma de México; 2000. p. $193-226$

Thoney DA, Hargis WJ Jr. Monogenea (Platyhelminthes) as hazards for fish in confinement. Annu Rev Fish Dis 1991; 1: 133-153. http://dx.doi. org/10.1016/0959-8030(91)90027-H.

Tort L. Stress and immune modulation in fish. Dev Comp Immunol 2011; 35(12): 1366-1375. http://dx.doi.org/10.1016/j.dci.2011.07.002. PMid:21782845.

Uribe C, Folch H, Enriquez R, Moran G. Innate and adaptive immunity in teleost fish: a review. Vet Med Czech 2011; 56(10): 486-503. http:// dx.doi.org/10.17221/3294-VETMED.

Ventura AS, Gabriel AMA, Saravy TM, Cavichiolo F. Descrição histopatológica das lesóes intestinais de híbrido patinga parasitado. Rev Ciên Vet Saúde Púb 2017; 4(1): 2-8. http://dx.doi.org/10.4025/revcivet. v4i1.34347.

Violante-González J, García-Varela M, Rojas-Herrera A, Guerrero SG. Diplostomiasis in cultured and wild tilapia Oreochromis niloticus in Guerrero State, Mexico. Parasitol Res 2009; 105(3): 803-807. http:// dx.doi.org/10.1007/s00436-009-1458-1. PMid:19452167.

Wang G, Kim JH, Sameshima M, Ogawa K. Detection of antibodies against the monogenean Heterobothrium okamoto $i$ in tiger puffer by ELISA. Fish Pathol 1997; 32(3): 179-180. http://dx.doi.org/10.3147/jsfp.32.179.

Wanstall ST, Robotham PWJ, Thomas JS. Pathological changes induced by Pomphorhynchus laevis Muller (Acanthocephala) in the gut of rainbow trout, Salmo gairdneri Richardson. Z Parasitenkd 1986; 72(1): 105-114. http://dx.doi.org/10.1007/BF00927741. PMid:3962428.

Watts M, Munday BL, Burke CM. Immune responses of teleost fish. Aust Vet J2001; 79(8): 570-574. http://dx.doi.org/10.1111/j.1751-0813.2001. tb10753.x. PMid:11599820.

Whyte SK, Chappell LH, Secombes CJ. Protection of rainbow trout, Oncorhynchus mykiss (Richardson), against Diplostomum spathaceum (Digenea): the role of specific antibody and activated macrophages. J Fish Dis 1990; 13(4): 281-291. http://dx.doi.org/10.1111/j.1365-2761.1990. tb00784.x.

Whyte SK. The innate immune response of finfish-a review of current knowledge. Fish Shellfish Immunol 2007; 23(6): 1127-1151. http://dx.doi. org/10.1016/j.fsi.2007.06.005. PMid:17980622.

Wiegertjes GF, Forlenza M, Joerink M, Scharsack JP. Parasite infections revisited. Dev Comp Immunol 2005; 29(9): 749-758. http://dx.doi. org/10.1016/j.dci.2005.01.005. PMid:15936432.

Williams MA, Hoole D. Antibody response of the fish Rutilus rutilus to the metacestode of Ligula intesinalis. Dis Aquat Organ 1992; 12: 83-89. http://dx.doi.org/10.3354/dao012083. 
Woo PTK, Leatherland JF, Bruno DW. Fish diseases and disorders. Wallingford: CABI; 2011.

Wood BP, Matthews RA. The immune response of the thick-lipped grey mullet, Chelon labrosus (Risso, 1826), to metacercarial infections of Cryptocotyle lingua (Creplin, 1825). J Fish Biol 1987; 31(sA): 175-183. http://dx.doi.org/10.1111/j.1095-8649.1987.tb05310.x.

Xu Z, Parra D, Gómez D, Salinas I, Zhang YA, von Gersdorff Jørgensen $\mathrm{L}$, et al. Teleost skin, an ancient mucosal surface that elicits gut-like immune responses. Proc Natl Acad Sci USA 2013; 110(32): 13097-13102. http:// dx.doi.org/10.1073/pnas.1304319110. PMid:23884653.

Ye J, Kaatari IM, Ma C, Kaattari S. The teleost humoral immune response. Fish Shellfish Immunol 2013; 35(6): 1719-1728. http://dx.doi. org/10.1016/j.fsi.2013.10.015. PMid:24436975.

Zapata A, Diez B, Cejalvo T, Gutiérrez-de Frías C, Cortés A. Ontogeny of the immune system of fish. Fish Shellfish Immunol 2006; 20(2): 126136. http://dx.doi.org/10.1016/j.fsi.2004.09.005. PMid:15939627.
Zhang YA, Salinas I, Li J, Parra D, Bjork S, Xu Z, et al. IgT, a primitive immunoglobulin class specialized in mucosal immunity. Nat Immunol 2010; 11(9): 827-835. http://dx.doi.org/10.1038/ni.1913. PMid:20676094.

Zhang YA, Salinas I, Oriol Sunyer J. Recent findings on the structure and function of teleost IgT. Fish Shellfish Immunol 2011; 31(5): 627-634. http://dx.doi.org/10.1016/j.fsi.2011.03.021. PMid:21466854.

Zhou S, Li WX, Zou H, Zhang J, Wu SG, Li M, et al. Expression analysis of immune genes in goldfish (Carassius auratus) infected with the monogenean parasite Gyrodactylus kobayashii. Fish Shellfish Immunol 2018; 77: 40-45. http://dx.doi.org/10.1016/j.fsi.2018.03.033. PMid:29567133.

Zhu LY, Pan PP, Fang W, Shao JZ, Xiang LX. Essential role of IL-4 and IL-4R $\alpha$ interaction in adaptive immunity of zebrafish: insight into the origin of Th2-like regulatory mechanism in ancient vertebrates. J Immunol 2012; 188(11): 5571-5584. http://dx.doi.org/10.4049/ jimmunol.1102259. PMid:22547699. 